\title{
Quantitation of Tropoelastin mRNA and Assessment of Alternative Splicing in Human Skin Fibroblasts by Reverse Transcriptase-Polymerase Chain Reaction
}

\author{
Martin Holzenberger, ${ }^{1}$ Simona A. Levi-Minzi, Christopher P. Herzog, Susan B. Deak, \\ Ladislas Robert, ${ }^{2}$ and Charles D. Boyd
}

Department of Surgery, UMDNJ-Robert Wood Johnson Medical School, New Brunswick, New Jersey $08903 ;{ }^{1}$ Institut d'Embryologie Cellulaire et Moleculaire, CNRS and College de France, 94736 Nogent-sur-Marne, France; ${ }^{2}$ Laboratoire de Biologie du Tissu Conjonctif, Universite de Paris XII, 94010 Creteil, France

We have developed a reverse transcriptase-polymerase chain reaction (RT-PCR) assay for the quantitative measurement of levels of tropoelastin mRNA in total RNA preparations from skin fibroblasts. This method facilitates the reproducible detection of low abundance tropoelastin mRNA in the range of 10-1000 copies per cell. The procedure is based on a competitive RT-PCR assay where a tropoelastin CDNA-derived internal RNA standard is cotranscribed and coamplified together with the sample derived-endogenous target mRNA. In addition, RT-PCR of several domains of tropoelastin $m R N A$, followed by DNA sequence analysis of asymmetric PCR products, revealed a previously unknown pattern of alternate exon usage at the $3^{\prime}$ end of the tropoelastin gene in human skin fibroblasts.
E lastin is the major component of elastic fibers that provide tissues such as blood vessels, lung, and skin with the properties of resilience. Hydrophobic and extensively cross-linked, elastin is assembled from a soluble precursor, tropoelastin. Over the last few years the complete derived amino acid sequence for several vertebrate tropoelastins, ${ }^{(1-3)}$ including human tropoelastin, ${ }^{(4)}$ have been reported. In addition, the structure of the gene coding for rat, bovine, and human tropoelastin has been described. ${ }^{(5-7)}$ These previous studies have revealed that several tropoelastin mRNA isoforms are synthesized from a complex multiexon gene by alternate usage of several exons within the tropoelastin gene.

Transcriptional control of expression of the tropoelastin gene and control of alternate exon usage is tightly regulated developmentally. ${ }^{(8-10)}$ In many elastic tissues, tropoelastin synthesis is maximal during embryonic or early neonatal development. ${ }^{(11)}$ In most normal elastic tissues from adult sources, however, little if any tropoelastin synthesis can be measured. ${ }^{(12)}$

Elastin is an important but minor component of cutaneous tissue. ${ }^{(13,14)} \mathrm{Al}-$ though no direct quantitative measurements of tropoelastin mRNA have been reported for intact skin, previous reports of tropoelastin mRNA recovery in cultured human skin fibroblasts have shown that this mRNA is a low abundance transcript. ${ }^{(15-18)}$ For this reason, particularly in cultured human skin fibroblasts, reproducible and quantitative detection of total tropoelastin mRNA has been limited. The low levels of tropoelastin mRNA in skin fibroblasts have also limited the accurate and quantitative characterization of patterns of alternative splicing of tropoelastin pre-mRNA that have been shown previously by cDNA cloning, DNA sequence, ${ }^{(3,4)}$ and S1 nuclease analysis ${ }^{(19,20)}$ to be present in a variety of elastic tissues, including skin. ${ }^{(15,21)}$

Alterations in elastic fiber morphology are known to be associated with the pathogenesis of a variety of adult onset cutaneous disorders such as pseudoxanthoma elasticum, acquired forms of cutis laxa, and actinic elastosis. ${ }^{(15,22)}$ Several investigators have suggested that alterations in the temporal control of total tropoelastin synthesis and the regulation of isoform expression may contribute to the abnormal assembly of elastic fibers. ${ }^{(23,24)}$ To begin to address this possibility, this paper describes a PCR-based assay to assess both the quantitative recovery of total tropoelastin mRNA and the extent of alternative splicing of the primary transcripts of the tropoelastin gene in cultured skin fibroblasts.

\section{MATERIALS AND METHODS}

\section{Materials}

All reagents were of ultrapure or equivalent grade and were obtained from U.S. Biochemical (Cleveland, $\mathrm{OH}$ ). Sequenase 
and DNA sequencing kits were also obtained from U.S. Biochemical. Tissue culture reagents were provided either by GIBCO-BRL (Grand Island, NY) or Flow Laboratories (McLean, VA). RNAzol B was purchased from Cinna-Biotecx Laboratories (Houston, TX). All restriction enzymes were supplied by Pharmacia (Piscataway, NJ). Bluescript vectors and RNA transcription kits were obtained from Stratagene (La Jolla, CA). Oligonucleotides were synthesized by National Biosciences (Plymouth, MN). Reverse transcriptase-polymerase chain reaction (RT-PCR) kits and Taq DNA polymerase were obtained from Perkin-Elmer (Norwalk, CT). Radioisotopes were purchased from ICN Radiochemicals (Irvine, CA). The thermocycler used for all of the PCR incubations described in this manuscript was purchased from MJ Research (Watertown, MA). Nylon membranes were obtained from Amersham Corporation (Arlington Heights, IL). Geneclean kits were provided by Bio101 (La Jolla, CA).

\section{Sample Preparation}

\section{Cell Culture}

Human skin fibroblasts were grown from skin biopsy explants of healthy individuals or from patients who underwent surgery for reasons unrelated to any cutaneous disorder. Biopsies were taken from skin not exposed to the sun. Human skin fibroblasts from passages 3 to 5 were grown to confluence in Dulbecco's modified Eagle medium (DMEM) supplemented with 10\% fetal bovine serum, antibiotics $(100 \mathrm{U} / \mathrm{ml}$ of penicillin $\mathrm{G}, 100 \mu \mathrm{g} / \mathrm{ml}$ of streptomycin sulfate, $0.25 \mu \mathrm{g} / \mathrm{ml}$ of amphotericin $B$, and $2 \mathrm{~mm}$ glutamine. Media were changed every 3-4 days. Before RNA extraction, the cells were washed twice in sterile phosphate buffered saline (PBS), trypsinized, and counted in a hemocytometer. Fibroblasts were immediately pelleted and the pellets washed in PBS at $4^{\circ} \mathrm{C}$. All subsequent steps of RNA isolation were done on ice.

\section{RNA Extraction}

Total RNA was extracted as described by Chomczynski and Sacchi, ${ }^{(25)}$ using a one-step phenol-chloroform procedure (RNAzol B). Between 1.8 and $5.2 \times 10^{6}$ cells were lysed in $0.9 \mathrm{ml}$ of RNAzol. Chloroform $(90 \mu \mathrm{l})$ was added to the ho- mogenate and vortexed for $15 \mathrm{sec}$. After 5 min on ice, phase separation was carried out by centrifugation at $12,000 \mathrm{~g}$ for $15 \mathrm{~min}$. The aqueous phase was removed and the RNA precipitated with isopropanol for $15 \mathrm{~min}$ at $-20^{\circ} \mathrm{C}$. After centrifugation for $15 \mathrm{~min}$ at $12,000 \mathrm{~g}$, the RNA pellets were washed in $75 \%$ (vol/vol) ethanol and resuspended in diethyl pyrocarbonate (DEPC)-treated water. RNA purity was assessed spectrophotometrically by determination of absorbance at 260 and $280 \mathrm{~nm}$ of each sample. RNA was diluted, aliquoted, and stored at $-70^{\circ} \mathrm{C}$.

\section{Transcript Quantitation Assay}

\section{Outline of Assay}

The basis for this quantitative PCR assay is the coamplification by RT-PCR of a 193-bp region of human tropoelastin mRNA from total RNA and RNA derived from a tropoelastin cDNA that is polymorphic at nucleotide position 1264 . $^{\text {(26) }}$ This polymorphism is an $A \rightarrow G$ substitution (the cDNA corresponds to the A allele) that creates a BstNI restriction site. The amplified PCR products from fibroblast RNA and the internal cRNA standard can readily be separated, therefore, by polyacrylamide gel electrophoresis (PAGE) following a BstNI digestion, provided that the RNA is derived from an individual donor who is homozygous for the $\mathrm{G}$ allele. Individuals used in this study, consequently, were initially genotyped by PCR amplification of total fibroblast RNA and PAGE analysis of BstNI digestion products obtained from the
PCR incubation. Quantitative estimates of tropoelastin mRNA were then determined from a mixture of fibroblast RNA from individuals homozygous for the G-allele and serial dilutions of known amounts of the internal A-allele cRNA standard (Fig. 1).

\section{Internal Standard}

A human tropoelastin cDNA covering sequences complementary to exons 1836 was subcloned into pBluescript (pTE1836). The sequence of this recombinant included an $\mathrm{A}$ at nucleotide position 1264. Sense-oriented complementary RNA was prepared from this template by in vitro transcription.

\section{In Vitro Transcription}

pTE1836 $(20 \mu \mathrm{g})$ was linearized with KpnI, extracted with phenol-chloroform, and ethanol precipitated, and an aliquot was analyzed by agarose gel electrophoresis to confirm complete digestion.

Linearized template $(1 \mu \mathrm{l})$ was transcribed in vitro using T3 RNA polymerase and incubation conditions outlined by the supplier of an RNA transcription kit (Stratagene). The reaction was terminated by DNase digestion and extracted with phenol-chloroform, and RNA was obtained by ethanol precipitation. After resuspension in DEPCtreated, double-distilled water, RNA concentration was determined spectro-

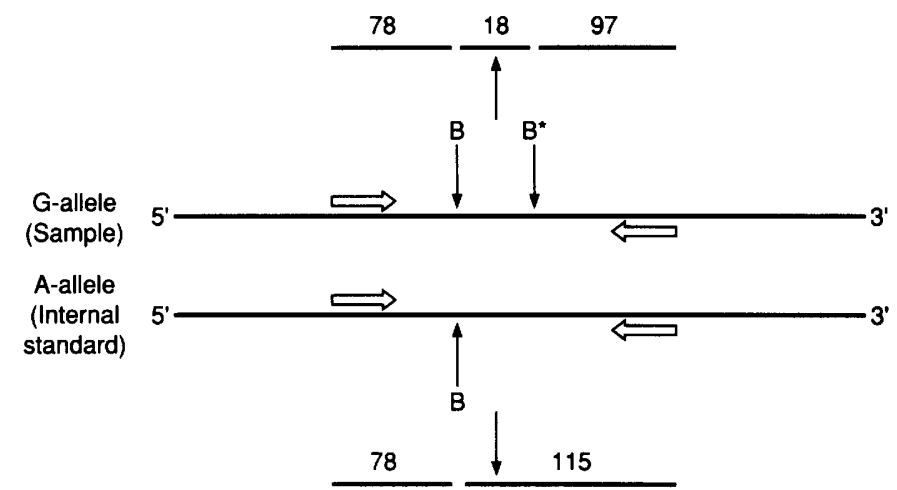

FIGURE 1 A schematic representation of restriction fragments generated by BstNI digestion of PCR products obtained from sample RNA and internal standard cRNA. The G allele, represented in tropoelastin mRNA isolated from cultured skin fibroblasts, contains an additional BstNI restriction site $\left(B^{*}\right)$, which is attributable to an $A \rightarrow G$ substitution at position 1264 . The size of the restriction fragments generated from both $G$ and $A$ alleles are presented in base pairs. $B$ identifies a nonpolymorphic BstNI restriction site. The open arrows represent the positions of oligomers used in the PCR amplification of this domain of human tropoelastin mRNA. 
photometrically and aliqouts of this sense strand were stored at $-70^{\circ} \mathrm{C}$.

\section{Oligonucleotides}

RT reactions were primed using a 10-mer sequence complementary to human tropoelastin mRNA from nucleotides 1402 to 1411 (5'-TGCCGCGTGG-3'). The melting temperature $\left(T_{\mathrm{d}}\right)$ of this primer was $44.6^{\circ} \mathrm{C} .^{(27,28)}$ A 17 -mer (5'-CGGAGTTGGAGGCATTC-3', $T_{\mathrm{d}}=61.6^{\circ} \mathrm{C}$ ) and an 18-mer $\quad\left(5^{\prime}\right.$-ACCGTACTTGGCAGCCTT$3^{\prime}, T_{\mathrm{d}}=62.1^{\circ} \mathrm{C}$ ) were designed as PCR primers to amplify the 193-bp target region between nucleotides 1167 and 1359 of the tropoelastin cDNA, following suggestions of Rychlik et al. ${ }^{(29)}$ and Rychlik ${ }^{(30)}$.

\section{$R T-P C R$}

Variable ratios of fibroblast RNA and tropoelastin cRNA were amplified in parallel. The RT reaction was carried out at $42^{\circ} \mathrm{C}$ for $15 \mathrm{~min}$ in a $5-\mu \mathrm{l}$ volume followed by a 5 -min inactivation step at $99^{\circ} \mathrm{C}$. Reaction conditions were as described by the supplier of a RT-PCR kit.

Amplification of single-stranded DNA was catalyzed by Taq polymerase in a programmable thermal cycler. Samples were prepared by combining $5 \mu$ l of the newly synthesized single-stranded DNA with $20 \mu \mathrm{l}$ of PCR buffer containing 50 $\mathrm{mm} \mathrm{KCl}, 10 \mathrm{~mm}$ Tris- $\mathrm{HCl}$ (pH 8.3), $15 \mathrm{~mm}$ $\mathrm{MgCl}_{2}, 0.01 \%$ (wt/vol) gelatin, $200 \mu \mathrm{M}$ of each dNTP, and $0.5 \mu$ l of $\left[\alpha-{ }^{32} \mathrm{P}\right] \mathrm{dCTP}$ (3000 Ci/mmole). The incubation was heated for $5 \mathrm{~min}$ at $95^{\circ} \mathrm{C}$ and $\mathrm{Taq}$ polymerase was then added. Cycling parameters were as follows: denaturation for 60 sec at $94^{\circ} \mathrm{C}$, annealing for $60 \mathrm{sec}$ at $61^{\circ} \mathrm{C}$ for the first 5 cycles, and at $60^{\circ} \mathrm{C}$ for all subsequent 25 cycles. The small size of the product did not require a $72^{\circ} \mathrm{C}$ elongation step. The final cycle consisted of a 5 -min incubation at $72^{\circ} \mathrm{C}$. All RT-PCR steps were done in the same tube under mineral oil protection using components from the GeneAmp RNA PCR kit.

\section{BstNI Digestion}

PCR reaction products were digested with 5 units of $B s t \mathrm{NI}$ at $60^{\circ} \mathrm{C}$ for $2 \mathrm{hr}$.

\section{PAGE Analysis}

Digestion fragments were size separated on $12 \%$ polyacrylamide gels at $250 \mathrm{~V}$ for
$3.5 \mathrm{hr}$ and stained with $0.05 \%$ ethidium bromide. DNA fragments were visualized under UV light and excised. Polyacrylamide slices were counted on a Beckman LS1801 scintillation counter. Recovered disintegrations per minute (dpm) were corrected for background and dCMP content in individual DNA fragments.

\section{RT-PCR Splicing Assay}

\section{Oligonucleotides}

Three exon-specific primer pairs were established to incorporate exons 11-17, 21-29, and 29-36. The $5^{\prime} \rightarrow 3^{\prime}$ sequences of these oligomers were as follows: an exon 11 oligomer, GGAGCTTTTGCTGGAATCCC; an exon 17 oligomer, GCTGC AGCTGGAGTCCCAAC; an exon 21 oligomer, TCAGGCAGCAGCTGCCG; an exon 29 downstream oligomer (antisense), CGGCTTTGGCAGCAGCTT; an exon 29 upstream oligomer (sense), AGCCAAAGCTGCTGCCAAAG; and an exon 36 oligomer, TTCTCTTCCGGCCACAAGCT.

\section{RT-PCR Conditions}

RT reactions were performed as described earlier, using $400 \mathrm{ng}$ of total RNA per $20-\mu l$ reaction. PCR conditions were as described by Perkin-Elmer except that $2 \mathrm{mM} \mathrm{MgCl}_{2}, 200 \mu \mathrm{M}$ dNTP each, $0.15 \mu \mathrm{M}$ primer, and 2.5 units of Taq polymerase were used per $100-\mu 1$ reaction. Initial strand separation was programmed for 5 $\min$ at $95^{\circ} \mathrm{C}$. The first 5 cycles were allowed to anneal at $68^{\circ} \mathrm{C}$ for $60 \mathrm{sec}$; all subsequent cycles were carried out at $67^{\circ} \mathrm{C}$ (27 cycles for primer pairs $11-17$ and 21-29, 32 cycles for primer pair 2936). Primer concentration was reduced to $0.10 \mu \mathrm{M}$ for primer pair $21-29 ; \mathrm{MgCl}_{2}$ concentration was lowered to $1.5 \mathrm{~mm}$ for amplification of the tropoelastin mRNA domain corresponding to exons 29-36.

\section{PAGE and Southern Blot Analysis}

Products were size separated on 5-8\% polyacrylamide gels, and DNA fragments were visualized by staining with ethidium bromide. Fragment sizes were determined by comparison with a 1-kb DNA molecular weight ladder.

Southern analysis was performed essentially as described by Sambrook et al. ${ }^{(31)}$ Briefly, PCR products were size separated by electrophoresis followed by capillary transfer onto a nylon membrane. Nylon membranes were probed with radiolabeled exon-specific oligonucleotides from exons $12,26,31,32$, and 33. Aliquots of each oligomer ( $150 \mathrm{ng}$ ) were labeled with $100 \mu \mathrm{Ci}$ of $\left[\gamma^{-32} \mathrm{P}\right]$ dATP using T4 polynucleotide kinase and previously described reaction conditions. The exon-specific oligomers were as follows $\left(5^{\prime} \rightarrow 3^{\prime}\right)$ : exon 12 , CCCACTGGGGTATCCCATCA; exon 26, TGTCGGCGTCCCTGGACT; exon 31, GTATACCTCCAGCTGCAGCCG; exon 32, GTGCTGCTGGCCTTGGAGGT, and exon 33, GGCTTCGGATTGTCTCCCAT. Nylon membranes were prehybridized for $24 \mathrm{hr}$ and hybridized for $14 \mathrm{hr}$ at temperatures $15-20^{\circ} \mathrm{C}$ below the theoretical $T_{\mathrm{d}}$ of the probes. Posthybridization washing included $6 \times$ SSC at increasing temperatures up to $50^{\circ} \mathrm{C}$. Washed filters were finally exposed to $\mathrm{x}$-ray film for up to 3 days at $-70^{\circ} \mathrm{C}$.

\section{Asymmetric PCR (APCR) and Sequence Analysis}

PCR products from four independent amplifications of the region covering exons 29-36 were pooled and fractionated by PAGE. Single-stranded antisense cDNA was synthesized by asymmetric PCR with a downstream-to-upstream primer ratio of $25: 1$ and the product purified using the Geneclean procedure. A Sequenase kit was employed for all DNA sequencing reactions.

\section{RESULTS \\ Cell Culture and Cenotypes}

We cultured human skin fibroblasts from a total of 26 donors ranging in age from 6 mo to $90 \mathrm{yr}$. Cell number in confluent $75-\mathrm{cm}^{2}$ culture flasks decreased significantly with donor age: $5.12 \times 10^{6}$ cells per flask were obtained from biopsies from the youngest donor; $1.56 \times 10^{6}$ cells per flask were recovered from biopsies from the older donors. The total RNA content per cell $(8.6 \pm 3.9 \mathrm{pg} /$ cell $)$ was not related to the donor age. All 26 samples were genotyped; 6 donors (23\%) were A/A, 12 donors ( $46 \%$ ) were $A / G$, and 8 donors $(31 \%)$ were $G / G$. Only individuals homozygous for the $G$ allele were used for the quantitation experiments.

\section{Tropoelastin mRNA Quantitation}

Titration mixtures of sample RNA with 


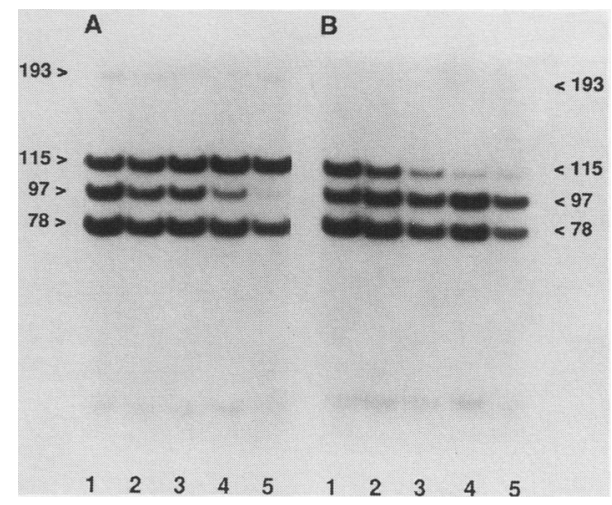

FIGURE 2 A fluorogram of BstNI restricuion fragments obtained from mixtures of total skin fibroblast and tropoelastin cRNA. $(A)$ Lanes 1-5 represent $B s t$ NI-digested PCR products obtained from $4.7 \times 10^{-3} \mathrm{pg}$ of the A-allele internal standard $(10,000 \mathrm{cRNA}$ molecules per reaction) and $25 \mathrm{ng}$ (lane 1), $10 \mathrm{ng}$ (lane 2), $5 \mathrm{ng}$ (lane 3), $2.5 \mathrm{ng}$ (lane 4), and $1 \mathrm{ng}$ (lane 5) per reaction of total RNA obtained from individual $\mathrm{HCH}$. $(B)$ Lanes $1-5$ represent BstNI-digested PCR products obtained from 5 ng of total RNA from individual IRW and $1 \times 10^{6}$ molecules (lane 1 ), $5 \times 10^{5}$ molecules (lane 2), $2 \times 15$ molecules (lane 3), $1 \times 10^{5}$ molecules (lane 4), and $5 \times 10^{4}$ molecules (lane 5) of the A-allele tropoelastin cRNA. Sizes of restriction fragments are indicated in base pairs.

internal cRNA standard were obtained in two ways. Either a serial dilution of synthetic internal cRNA standard was added to constant amounts of sample RNA or constant amounts of internal standard were added to a serial dilution of sample RNA. RT-PCR-amplified DNAs from these RNA mixtures were digested with BstNI. A 193-bp DNA fragment amplified from cRNA corresponding to the A allele (the internal standard) lacks a BstNI restriction site (Fig. 1). Two BstNI restriction fragments of 78 and 115-bp would therefore be obtained from this allele. The 193-bp DNA fragment recovered from tropoelastin mRNA obtained from donors homozygous for the G allele contains an additional $B s t \mathrm{NI}$ restriction site. The recovery of a 97-bp BstNI restriction fragment corresponds to the amplification of the $G$ allele. Illustrated in Figure 2 are representative fluorograms of these PCR-derived restriction fragments. In Figure $2 \mathrm{~A}$, a varying amount of the 97 bp BstNI restriction fragment reflects the variable input of tropoelastin mRNA from $\mathrm{G}$-allele donors. In Figure $2 \mathrm{~B}$, the variable amount of the 115 -bp restric- tion fragment represents the variable input of the A allele cRNA added to the RT-PCR reaction. In both examples, coamplification of a domain of TE mRNA of unknown abundance and a tropoelastin cRNA of known amount involves the identical coding sequences with the exception of a single nucleotide difference. A comparative quantitation of the recovery of allele-specific BstNI restriction fragments will therefore be independent of sequence-specific variation in rates of reverse transcription or polymerase chain amplification.

The quantitative determination of levels of tropoelastin mRNA represented in G-allele-specific PCR-derived BstNI restriction fragments is presented in Figure 3. Size-separated, radiolabeled DNA fragments of 115 and 97-bp were recovered within polyacrylamide gel slices. The amount of DNA was calculated from total dpm present in each gel slice. At equal levels of recovery of the 97-bp fragment (the sample) and the 115-bp fragment (the internal standard), levels of tropoelastin mRNA in the sample could be calculated. Levels of tropoelastin
mRNA were expressed as the recovery of molecules of tropoelastin mRNA per cell.

Recovered levels of tropoelastin mRNA in total RNA from skin fibroblast preparations from several donors vary from 14-845 mRNA transcripts per cell (Table 1). These levels of tropoelastin mRNA vary significantly with donor age but are independent of the gender of individual donors. The variation of mRNA levels with age is represented in Figure 4. There is a statistically significant decline in tropoelastin mRNA levels from a neonatal donor of 6 months of age to a donor of $23 \mathrm{yr}$ of age $(P<0.01)$. No change in mRNA levels was observed in fibroblast cultures established from donors 23-49 yr of age. A statistically significant increase in levels of tropoelastin mRNA was evident between donor ages of 49 and $79 \mathrm{yr}$.

\section{RT-PCR Detection of Isoforms of Human Tropoelastin mRNA}

RT-PCR analysis of the 3 ' end of human tropoelastin mRNA (from a number of fibroblast RNA preparations isolated

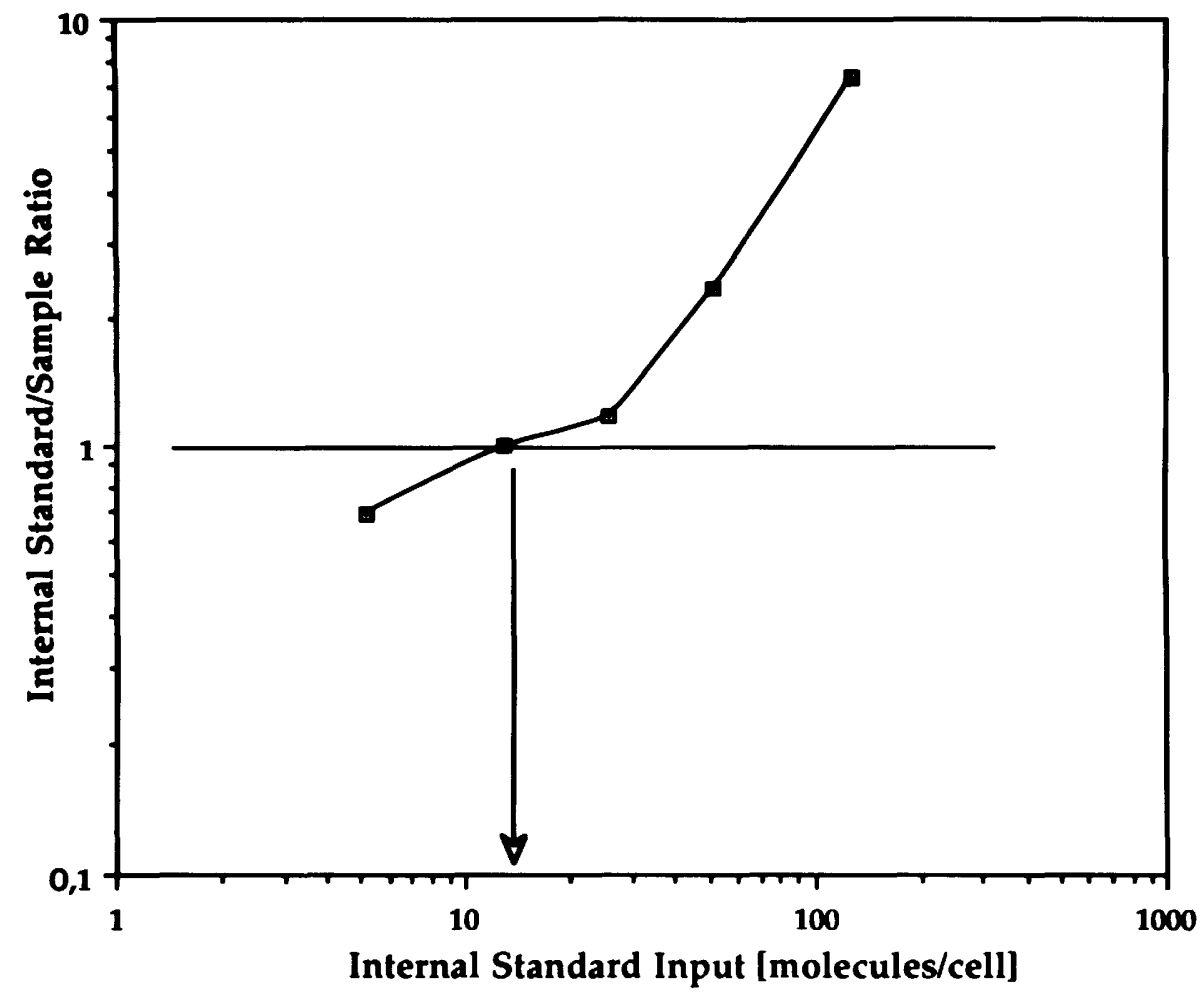

FIGURE 3 Determination of tropoelastin mRNA concentration. The amount of radiolabeled DNA synthesized from tropoelastin mRNA and tropoelastin cRNA was determined from polyacrylamide gel slices following electrophoresis and fluorography as described in Materials and methods and represented in Fig. 2. Tropoelastin mRNA content per cell was determined from the iternal standard at an mRNA/internal standard ratio of one (indicated with an arrow). 
TABLE 1 Tropoelastin mRNA Levels in Skin Fibroblasts from Donors Homozygous for the G Allele of an RFLP in Exon 20 of the Tropoelastin Gene

\begin{tabular}{|c|c|c|c|}
\hline $\begin{array}{l}\text { Individual } \\
\text { (initials) }\end{array}$ & $\operatorname{Sex}^{\mathrm{a}}$ & $\begin{array}{l}\text { Age } \\
\text { (yr) }\end{array}$ & $\begin{array}{l}\text { mRNA } \\
\text { molecules/cell } \\
\text { (mean } \pm \\
\text { S.E.M.) }\end{array}$ \\
\hline FNH & $\mathrm{M}$ & 67 & $212 \pm 68$ \\
\hline $\mathrm{HCH}$ & M & 28 & $66 \pm 32$ \\
\hline IRW & $\mathbf{F}$ & 74 & $445 \pm 205$ \\
\hline $\mathrm{KBB}$ & $\mathrm{M}$ & 24 & $14 \pm 6$ \\
\hline KDS & $\mathbf{F}$ & 0.5 & $350 \pm 60$ \\
\hline KDC & F & 23 & $71 \pm 29$ \\
\hline KST & F & 49 & $44 \pm 31$ \\
\hline MAS & $\mathrm{F}$ & 79 & $845 \pm 105$ \\
\hline
\end{tabular}

${ }^{a}$ The gender of individual donors is indicated as either $\mathrm{M}$ (male) or $\mathbf{F}$ (female).

from several unrelated donors) revealed two PCR fragments: an expected 284-bp DNA fragment and a 230-bp DNA fragment (Fig. 5).

Southern blot analysis of these PCRderived DNA fragments suggested that the shorter, 230-bp fragment lacked exon 32 (Fig. 6A). Dideoxy sequencing of single-stranded DNA obtained by asymmetric PCR from both these DNA fragments confirmed that the DNA sequence corresponding to exon 32 was absent from the 230-bp PCR-derived fragment (Fig. 6B).

\section{DISCUSSION}

Previous studies of elastic tissues such as nuchal ligament and aorta, in which elastin is an abundant component, have revealed that the bulk of tropoelastin synthesis occurs in the prenatal and neonatal stages of development. ${ }^{(8,11,32)}$ In adult elastic tissues, little if any tropoelastin synthesis can be detected. ${ }^{(33)}$ Consequently, steady-state levels of tropoelastin mRNA in total RNA preparations from tissues of adult sources are difficult to detect by traditional Northern blot analysis. ${ }^{(12)}$ Similarly, any quantitative estimate of the appearence of alternatively spliced variants of tropoelastin mRNA will be hampered by the low abundance of this message in tissue from adult sources.

In this paper we describe a RT-PCRbased assay for the rapid and reproducible quantitative measurement of

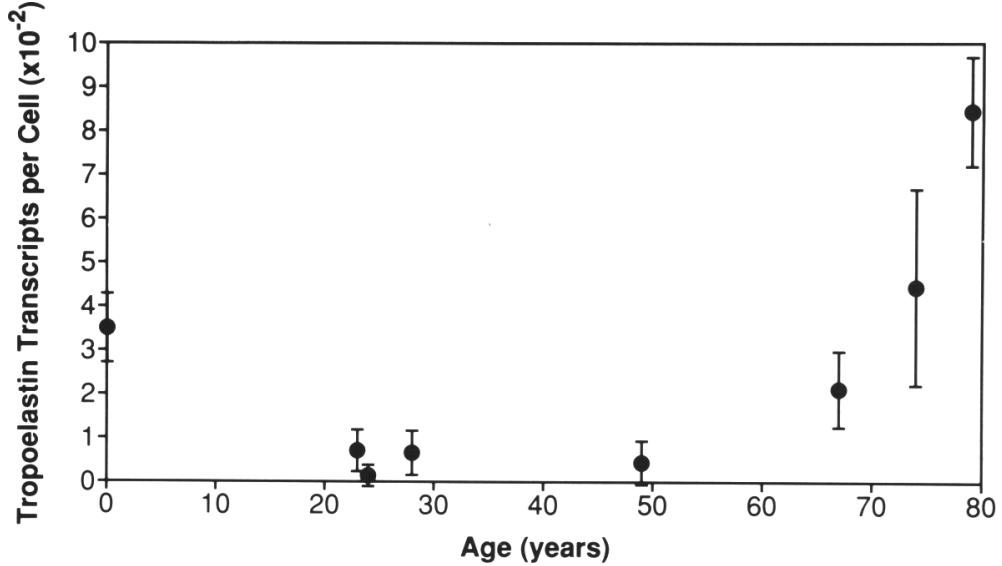

FIGURE 4 Tropoelastin mRNA content in skin fibroblasts from donors of different ages. Levels of tropoelastin mRNA were determined from eight donors varying in age from 6 months to $79 \mathrm{yr}$. The measurement of mRNA levels was determined from three separate RT-PCR reactions from individual total RNA preparations. The average results are presented with standard errors of the mean.

tropoelastin mRNA content. The development of the internal standard we used in this PCR assay took advantage of a recently reported restriction fragment length polymorphism (RFLP) within exon 20 of the human tropoelastin gene. ${ }^{(26)}$ To maintain an internal standard that was essentially identical with respect to size and DNA sequence, we chose not to use some of the multipurpose internal standards reported recently. ${ }^{(34-36)}$

The primers used to amplify a 193-bp

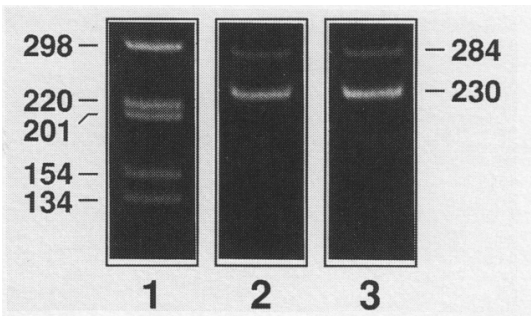

FIGURE 5 PAGE analysis of PCR products obtained from the amplification of a 3' domain of human tropoelastin mRNA from skin fibroblasts. Primers corresponding to coding domains within exons 29 and 36 of the human tropoelastin gene were used to generate PCR products using total skin fibroblast RNA. Aliquots of the PCR reaction were analyzed on $5 \%$ polyacrylamide gels. Following electrophoresis, DNA bands were visualized by staining with ethidium bromide. Lane 1 contains molecular weight markers. Lanes 1 and 2 are PCR products obtained from total RNA isolated from skin fibroblast cultures prepared from two donors. The sizes of DNA fragments are presented in base pairs. region of tropoelastin mRNA are derived from coding sequence complementary to domains in exons 18 and 21 . Any amplification from tropoelastin-coding sequence in genomic DNA contaminating the total RNA preparation or tropoelastin pre-mRNA present in total RNA would result in a higher molecular weight PCR product. No significant levels of higher molecular weight PCR products were noticeable, however.

Heterodimer formation between PCR products obtained from G-allele-derived tropoelastin mRNA and the A-allele cRNA internal standard will lead to $A-G$ heterodimers that will not be cleaved by $B s t \mathrm{NI}$; the detection of the undigested A-G heterodimer will result in an overrepresentation of the internal standard and under-representation of tropoelastin mRNA levels in the sample. Heterodimers are, however, a minor component during the exponential phase of PCR amplification. ${ }^{\left({ }^{(7)}\right)}$ Under the conditions described in this paper, heterodimer formation was usually $<8 \%$ of total PCR product produced.

Misincorporation of nucleotides during amplification attributable to the limited fidelity of transcription of Taq polymerase $^{(38)}$ could possibly generate additional G-allele mRNA sequence from the A-allele internal standard and consequently bias the apparent recovery of tropoelastin mRNA levels in a manner similar to the formation of heteroduplexes.

Whereas concerns of limited tran- 


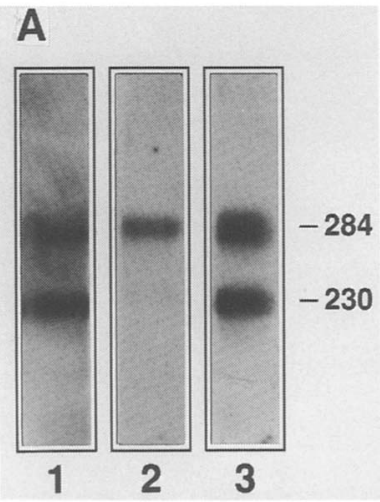

B

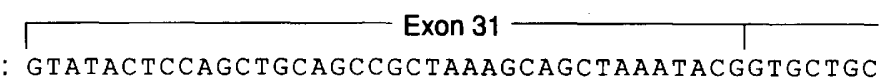

Sequence 1: GTATACTCCAGCTGCAGCCGCTAAAGCAGCTAAATACGGTGCTGC

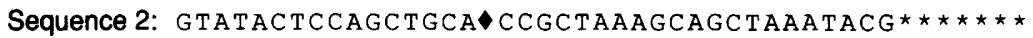

\section{Exon 32}

Sequence 1: TGGCCTTGGAGGTGTCCTAGGGGGTGCCGGGCAGTTCCCACTTGG

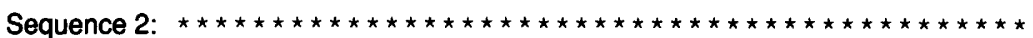

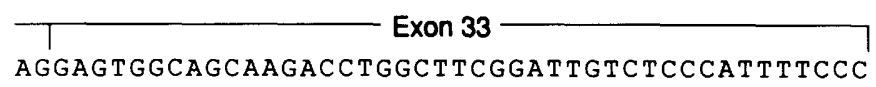

Sequence 1: AGGAGTGGCAGCAAGACCTGGCTTCGGATTGTCTCCCATTTTCCC Sequence 2: * *GAGTGGCAGCAAGACCTGGCTTCGGATTGTCTCC^ATTTCCC

FIGURE 6 Southern blot and DNA sequence analysis of PCR products obtained from the $3^{\prime}$ end of human tropoelastin mRNA. (A) The PCR products presented in Fig. 5 were analyzed by Southern blot analysis using radiolabeled, exon-specific oligomers. (Lanes 1-3) PCR products were probed with exon 30-, exon 32- and exon 33-specific oligomers, respectively. The sizes of the recovered DNA fragments are indicated in base pairs. (B) Dideoxy DNA sequence analysis of asymmetric PCR products obtained from PCR-derived DNA fragments amplified from the $3^{\prime}$ end of human skin fibroblast tropoelastin mRNA. The 284-bp and 230-bp DNA fragments visualized in Fig. 5 were extracted from polyacrylamide gels. APCR and dideoxy sequence analyses were carried out as described in Materials and methods. (Sequence 1) The DNA sequence obtained from the 284-bp fragment and is identical to previously published sequence for human tropoelastin. ${ }^{4}$ (Sequence 2 ) The DNA sequence obtained from the 230 -bp fragment. Sequences corresponding to exon domains are indicated. Diamonds represent nucleotides which, by comparison with sequence 1 , are different in sequence 2. Although these sequence differences may represent allelic variants within exon 31 and exon 33 , they occurred within regions of band compression in the DNA sequencing gels and most likely represent error in sequence 2 . Stars represent nucleotides missing in sequence 2 due to alternate exon usage.

scriptional fidelity of Taq polymerase could be reduced by the use of DNA polymerases with enhanced proofreading activity, ${ }^{(39)}$ when using the internal standard alone in control incubations, we have never found the recovery of a genotype different to the A allele defined by the internal standard.

In our preliminary studies of PCRbased protocols for the quantitation of tropoelastin mRNA, we compared estimated mRNA levels using a tropoelastin cRNA and a tropoelastin cDNA internal standard. The estimation of tropoelastin mRNA levels using a cDNA standard was $\sim 10$-fold lower compared with mRNA level estimations using a cRNA standard. Although the recovery of PCR product is dependent on the amount of RNA added to the PCR reaction, the large difference in mRNA estimation suggests that only a fraction of the tropoelastin mRNA or cRNA in any particular aliquot is reverse transcribed.

Several investigators have reported using between 20 and $250 \mathrm{ng}$ of total RNA per microliter of incubation sample. ${ }^{(36,37,40)}$ In contrast with these reports, but consistent with the work of Gilliland and co-workers, ${ }^{(41,42)}$ we found a linear response with respect to the synthesis of PCR product between 0.2 and 5 ng of total RNA added per microliter of incubation sample. We observed no increase in PCR product if $>10 \mathrm{ng}$ of total
RNA was added per microliter of incubation sample.

The assay described in this paper routinely detects levels of tropoelastin mRNA as low as 10 molecules per cell. These incubation conditions would not permit, however, the accurate and reproducible detection of $<10$ molecules per cell of tropoelastin mRNA.

We have measured successfully a 60 fold variation in the steady-state levels of tropoelastin mRNA obtained from lowpassage skin fibroblasts from donors of different ages. In confirmation of previous studies of tropoelastin mRNA levels in elastic tissues, ${ }^{(12,32)}$ we have demonstrated that levels of tropoelastin mRNA are elevated in fibroblast cultures from a neonatal donor and then decline with increasing age. Surprisingly, however, tropoelastin mRNA levels were found to increase in fibroblast cultures from elderly donors. Whereas the results presented are obtained from fibroblast preparations from relatively few donors, the low steady-state levels of tropoelastin mRNA from young adults was confirmed in triplicate determinations from four different donors ranging in age from 23 to $49 \mathrm{yr}$. Similarly, an increase in recovered levels of tropoelastin mRNA from more elderly donors (67-79 yr) was confirmed in three individuals. These results contrast with earlier observations by Fazio and co-workers ${ }^{(21)}$ who demon- strated an invariable recovery of steadystate levels of tropoelastin mRNA in skin fibroblasts up to a donor age of $33 \mathrm{yr}$, followed by an approximately sevenfold decrease in mRNA levels in cultured fibrobalsts from a single 61-yr-old donor. The reason (or reasons) for the discrepancy in the results of these two studies is not clear; it is possible that age-independent variation in tropoelastin mRNA levels may contribute to this discrepancy. Fazio and co-workers ${ }^{(15)}$ for example, only reported tropoelastin mRNA levels for a single elderly donor. Although our own data are based on steady-state levels of tropoelastin mRNA from a total of eight individuals, it is clear that a larger number of fibroblast cultures from normal donors is a necessary prerequisite for a more complete study. In addition, neither study addresses tropoelastin mRNA levels in intact skin. In contrast with previous techniques of Northern or slot blot hybridization, the sensitivity and reproducibility of the RT-PCR-based protocol described in this manuscript should make it possible to quantitate levels of tropoelastin mRNA directly in a large number of skin punch biopsies.

To obtain the eight individuals, homozygous for the $G$ allele, from which we report these steady-state levels of tropoelastin mRNA, we used RNA from skin fibroblast cultures to genotype a total of 26 individuals. A limitation therefore of 
the current protocol is that approximately two-thirds of the donors could not be used for tropoelastin mRNA quantitation. The construction of a G-allele internal standard would permit the use of donors homozygous for the A allele and significantly increase the number of donors that could be utilized for quantitation of tropoelastin mRNA.

Our approach of utilizing exon-encoded polymorphisms as the basis for an internal standard for mRNA quantitation is not limited to the quantitation of tropoelastin mRNA. RFLPs within exons of several other genes, including genes coding for connective tissue proteins, could also be employed. For example, a $\mathrm{G} \rightarrow \mathrm{A}$ allelic variant in exon 31 of the proa 1 (III) collagen (COL3A1) gene ${ }^{(43)}$ would be an appropriate polymorphism for the quantitation of levels of pro 1 (III) collagen mRNA. Similarly, a G $\rightarrow$ A transition within exon 1 of the human lysyloxidase gene ${ }^{(44)}$ would be an excellent allelic variant for use in a quantitative assay of lysyloxidase mRNA levels.

RT-PCR, Southern blot, and DNA sequence analysis of the $3^{\prime}$ end of the human tropoelastin mRNA derived from several skin fibroblast cultures revealed the consistent presence of a tropoelastin mRNA isoform that lacked exon 32 . This finding is consistent with previous reports of alternate usage of exon 32 in human skin fibroblasts. ${ }^{(6)}$ However, there was no evidence for alternate usage of exon 33 in these human skin fibroblast RNA preparations. Exon 33 has been shown by several investigators to be subject to alternate usage in a variety of tissues from several species and at different stages of development. ${ }^{(10,21,45)}$ Exon 33 also encodes a highly conserved hydrophobic domain of tropoelastin. The developmental and tissue-specific regulation of alternate usage of exon 33 in several rat elastic tissues led to the suggestion that alternate usage of this exon may be significant for tissue-specific fiber assembly. ${ }^{(45)}$ Similarly, the absence of any detectable alternate usage of exon 33 in skin fibroblasts may be an important contributing factor to the assembly of the morphologically distinct dermal elastic fibers.

\section{ACKNOWLEDGMENTS}

This work was supported by National Institutes of Health grants HL 37438 and HL 39864 . M.H. is a recipient of a post- doctoral fellowship of the Deutsche Forschungsgemeinschaft (HO 1208/1-2). We gratefully acknowledge the assistance of Paula Belem and Eva Botai in the typing of this manuscript.

\section{REFERENCES}

1. Bressan, G.M., P. Argos, and K.K. Stanley. 1987. Repeating structure of chick tropoelastin revealed by complementary DNA cloning. Biochemistry 26: 14971503.

2. Raju, K. and R.A. Anwar. 1987. Primary structure of bovine elastin $a, b$, and $c$ deduced from the sequences of cDNA clones. J. Biol. Chem. 262: 5755-5762.

3. Pierce, R.A., S.B. Deak, C.A. Stolle, and C.D. Boyd. 1990. Heterogeneity of rat tropoelastin mRNA revealed by cDNA cloning. Biochemistry 29: 9677-9683.

4. Indik, Z., H. Yeh, N. Ornstein-Golstein, P. Sheppard, N. Anderson, J.C. Rosenbloom, L. Peltonen, and J. Rosenbloom. 1987. Alternative splicing of human elastin mRNA indicated by sequence analysis of cloned genomic and complementary DNA. Proc. Natl. Acad. Sci. 84: 5680-5684.

5. Indik, Z., K. Yoon, S.D. Morrow, G. Cicila, J. Rosenbloom, J. Rosenbloom, and N. Ornstein-Goldstein. 1987. Structure of the $3^{\prime}$ region of the human elastin gene: Great abundance of Alu repetitive sequences and few coding sequences. Connect. Tissue Res. 16: 197-211.

6. Bashir, M.M., Z. Indik, H. Yeh, N. Ornstein-Goldstein, J.C. Rosenbloom, W. Abrams, M. Fazio, J. Uitto, and J. Rosenbloom. 1989. Characterization of the complete human elastin gene. J. Biol. Chem. 264: 8887-8891.

7. Pierce, R.A., A. Alatawi, S.B. Deak, and C.D. Boyd. 1992. Elements of the rat tropoelastin gene associated with alternative splicing. Genomics 12: 651-658.

8. Davidson, J.M., K. Smith, S. Shibahara, P. Tolstoshev, and R.G. Crystal. 1982. Regulation of elastin synthesis in developing sheep nuchal ligament by elastin mRNA levels. J. Biol. Chem. 257: 747-754.

9. Davidson, J.M., S. Shibahara, C.D. Boyd, M.L. Mason, P. Tolstoshev, and R.G. Crystal. 1984. Elastin mRNA levels during foetal development of sheep nuchal ligament and lung. Biochem. J. 220: 653-663.

10. Heim, R.A., R.A. Pierce, S.B. Deak, D.J. Riley, C.D. Boyd, and C.A. Stolle. 1991. Alternative splicing of rat tropoelastin mRNA is tissue specific and developmentally regulated. Matrix 11: 359-366.

11. Keeley, F.W., R.A. Hussain, and D.J. Johnson. 1990. Pattern of accumulation of elastin and the level of mRNA for elastin in aortic tissue of growing chickens. Arch. Biochem. Biophys. 282: 226-232.

12. Parks, W.C., H. Secrist, L.C. Wu, and R.P.
Mecham. 1988. Developmental regulation of tropoelastin isoforms. J. Biol. Chem. 262: 4416-4423.

13. Uitto, J., J.L. Paul, K. Brockley, R.H. Pearce, and J.G. Clark. 1983. Elastic fibers in human skin. Quantitation of elastic fibers by computerized digital image analysis and determination of elastin by radioimmunoassay of desmosin. Lab. Invest. 49: 499-505.

14. Uitto, J., M.J. Fazio, and D.R. Olsen. 1989. Molecular mechanisms of cutaneous aging. J. Am. Acad. Dermatol. 21: 614-622.

15. Fazio M., D. Olsen, H. Kuivaniemi, M. Chu, J. Davidson, J. Rosenbloom, and J. Uitto. 1988. Isolation and characterization of human elastin cDNAs, and ageassociated variation in elastin gene expression in cultured skin fibroblasts. $L a b$. Invest. 58: 270-277.

16. Olsen, D.R., M.J. Fazio, A.T. Shamban, J. Rosenbloom, and J. Uitto. 1988. Cutis laxa: Reduced elastin gene expression in skin fibroblast cultures as determined by hybridization with a homologous cDNA and an exon 1-specific oligonucleotide. J. Biol. Chem. 263: 6465-6467.

17. Sephel, G.C., A. Sturrock, M.G. Giro, and J.M. Davidson. 1988. Increased elastin production by progeria skin fibroblasts is controlled by the steady state levels of elastin mRNA. J. Invest. Dermatol. 90: 643-647.

18. Sephel, G.C., P.H. Byers, K.A. Holbrook, and J.M. Davidson. 1989. Heterogeneity of elastin expression in cutis laxa fibroblast strains. J. Invest. Dermatol. 93: 147153.

19. Yeh, H., N. Anderson, N. Ornstein-Goldstein, Z. Indik, P. Sheppard, J.C. Rosenbloom, G. Cicila, K. Yoon, and J. Rosenbloom. 1987. Sequence variation of bovine elastin mRNA due to alternative splicing. Collagen Relat. Res. 7: 235-247.

20. Yeh, H., N. Anderson, N. Ornstein-Goldstein, M.M. Bashir, J.C. Rosenbloom, W. Abrams, Z. Indik, K. Yoon, W.C. Parks, R. Mecham, and J. Rosenbloom. 1989. Structure of the bovine elastin gene and S1 nuclease analysis of alternative splicing of elastin mRNA in the bovine nuchal ligament. Biochemistry 28: 2365-2370.

21. Fazio, M.J., R.O. David, A.K. Eunkyung, T.B. Clinton, Z. Indik, N. Ornstein-Goldstein, H. Yeh, J. Rosenbloom, and J. Uitto. 1988. Cloning of full length elastin $\mathrm{cD}$ NAs from a human skin fibroblast recombinant cDNA library: Further elucidation of alternative splicing utilizing exon-specific oligonucleotides. J. Invest. Dermatol. 91: 458-464.

22. Rosenbloom, J. 1984. Elastin: Relation of protein and gene structures to disease. Lab. Invest. 51: 605-622.

23. Boyd, C.D., A.M. Christiano, R.A. Pierce, A. Alatawi, J.W. Mackenzie, and S.B. Deak. 1991. Elastic fibers-A primary role in dis- 
eases of elastic tissue? In The extracellular matrix of the uterus, cervix and fetal membranes (ed. P.C. Leppert and F. Woessner), pp. 3-14. Perinatology Press, Ithaca, New York.

24. Parks, W.C. and S.B. Deak. 1990. Tropoelastin heterogeneity: Implications for protein function and disease. Am. I. Respir. Cell Mol. Biol. 2: 399-406.

25. Chomczynski, P. and N. Sacchi. 1987. Single-step method of RNA isolation by acid guanidinium thiocyanate-phenol-chloroform extraction. Annal. Biochem. 162: 156-159.

26. Tromp, G., A. Christiano, N. Goldstein, Z. Indik, C. Boyd, J. Rosenbloom, S. Deak, D. Prockop, and H. Kuivaniemi. 1991. A to G polymorphism in ELN gene. Nucleic Acids Res. 19: 4314.

27. Rychlik, W. and R.E. Rhoads. 1989. A computer program for choosing optimal oligonucleotides for filter hybridisation, sequencing and in vitro amplification of DNA. Nucleic Acids Res. 17: 8543-8551.

28. Breslauer, K.J., R. Frank, H. Blocker, and L.A. Marky. 1986. Predicting DNA duplex stability from the base sequence. Proc. Natl. Acad. Sci. 83: 3746-3750.

29. Rychlik, W., W.J. Spencer, and R.E. Rhoads. 1990. Optimization of the annealing temperature for DNA amplification in vitro. Nucleic Acids Res. 18: 64096412.

30. Rychlik, W. 1993. Selection of primers for PCR. Methods Mol. Biol. (in press).

31. Sambrook, J., E.F. Fritsch, and T. Maniatis. 1989. Molecular cloning: A laboratory manual, 2nd ed. Cold Spring Harbor Laboratory Press, Cold Spring Harbor, New York.

32. Foster, J.A. and S.W. Curtiss. 1990. The regulation of lung elastin synthesis. Am. J. Physiol. 259: L13-23.

33. Davidson, J.M., K.E. Hill, and J.L. Alford. 1986. Developmental changes in collagen and elastin biosynthesis in the porcine aorta. Dev. Biol. 118: 103-111.

34. Wang, A.M., M.V. Doyle, and D.F. Mark. 1989. Quantitation of mRNA by the polymerase chain reaction. Proc. Natl. Acad. Sci. 86: 9717-9721.

35. Funk, C.D. and G.A FitzGerald. 1991. Eicosanoid forming enzyme mRNA in human tissues. J. Biol. Chem. 266: 1250812513.

36. Bouaboula, M., P. Legoux, B. Pessegue, B. Delpech, X. Dumont, M. Piechazyk, P. Casellas, and D. Shire. 1992. Standardization of mRNA titration using a polymerase chain reaction method involving co-amplification with a multispecific internal control. J. Biol. Chem. 267: 21830-21838.

37. Becker-Andre, $M$. and K. Hahlbrook. 1989. Absolute mRNA quantification using the polymerase chain reaction (PCR). A novel approach by a PCR aided transcript titration assay (PATTY). Nucleic Acids Res. 17: 9437-9446.
38. Gyllensten, U. 1989. Direct sequencing of in vitro amplified DNA. In PCR technology. principles and applications for DNA amplification (ed. H.A. Erlich), pp. 45-60. Stockton Press, New York.

39. Keohavong, P. and W.G. Thilly. 1989. Fidelity of DNA polymerases in DNA amplification. Proc. Natl. Acad. Sci. 86: 92539257.

40. Ikonen, E., T. Manninen, I. Peltonen, and A.C. Sylvanen. 1992. Quantitative determination of rare mRNA species by PCR and solid phase microsequencing. $P C R$ Methods Applic. 1: 234-240.

41. Gilliland, G., S. Perrin, K. Blanchard, and H.F. Bunn. 1990. Analysis of cytokine mRNA and DNA: Detection and quantitation by competitive polymerase chain reaction. Proc. Natl. Acad. Sci. 87: 27252729.

42. Gilliland, G., S. Perrin, and H.F. Bunn. 1990. Competitive PCR for quantitation of mRNA. In PCR protocols: $A$ guide to methods and applications (ed. M.A. Innis, D.H. Gelfand, J.J. Sninsky, and T.J. White), pp. 60-69. Academic Press, San Diego, CA.

43. Zafarullah, K., C. Kleinert, G. Tromp, H. Kuivaniemi, S. Kontusaari, Y. Wu, A. Ganguly, and D.J. Prockop. 1990. G to A polymorphism in exon 31 of the COL3A1 gene. Nucleic Acids Res. 18: 6180.

44. Csiszar, K., T.J. Mariani, J.S. Gosin, S.B. Deak, and C.D. Boyd. 1993. A restriction fragment length polymorphism results in a nonconservative amino acid substitution encoded within the first exon of the human lysyl oxidase gene. Genomics 16: 401-406.

45. Boyd, C.D., A.M. Christiano, R.A. Pierce, C.A. Stolle, and S.B. Deak. 1991. Mammalian tropoelastin: Multiple domains of the protein define an evolutionarily divergent amino acid sequence. Matrix 11: 235-241.

Received May 17, 1993; accepted in revised form Iuly 27, 1993. 


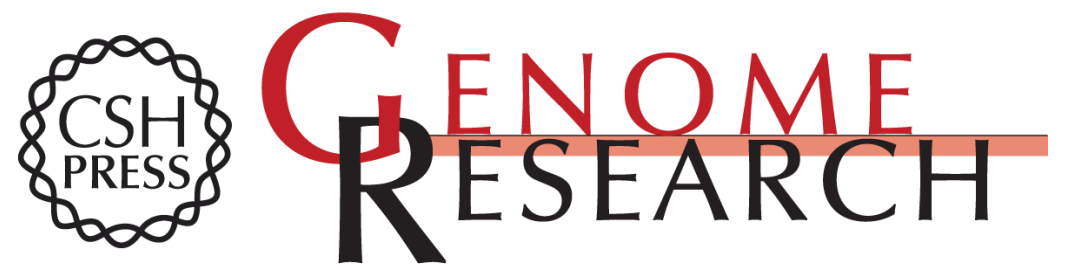

\section{Quantitation of tropoelastin mRNA and assessment of alternative splicing in human skin fibroblasts by reverse transcriptase-polymerase chain reaction.}

M Holzenberger, S A Levi-Minzi, C P Herzog, et al.

Genome Res. 1993 3: 107-114

Access the most recent version at doi:10.1101/gr.3.2.107

References This article cites 40 articles, 12 of which can be accessed free at:

http://genome.cshlp.org/content/3/2/107.full.html\#ref-list-1

\section{License}

Email Alerting

Receive free email alerts when new articles cite this article - sign up in the box at the Service top right corner of the article or click here.

\section{Affordable, Accurate Sequencing.}

To subscribe to Genome Research go to:

https://genome.cshlp.org/subscriptions 